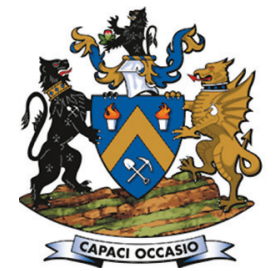

Affiliation:

1 Leon Roux Retired from Exxaro's Grootegeluk Coal Mine and continued with the Clean Coal Research Group at the University of the Witwatersrand during his research years preparing for this paper. Post Humous.

Correspondence to:

L. Roux

M. van Aswegen

Email:

marcia.vanaswegen@dataminesoftware.com

Dates:

Received: 12 Nov. 2020

Revised: 1 Jun. 2021

Accepted: 2 Nov. 2021

Published: November 2021

\section{How to cite:}

Roux, L. 2021

A critical review of initial Resource and Reserve tonnage estimation and reporting.

Journal of the Southern African Institute of Mining and Metallurgy, vol. 121, no. 11, pp. 607-616

DOI ID:

http://dx.doi.org/10.17159/2411$9717 / 1427 / 2021$

\title{
A critical review of initial Resource and Reserve tonnage estimation and reporting
}

\author{
by L. Roux
}

\section{Synopsis}

This review was initially motivated by the author's own experience in attempting to reconcile run-ofmine production tons with the Coal Resource and Reserve estimation of mineable, in-situ tonnages. The primary scientific measurements and observations that are collected during exploration at the beginning of the value chain will have a profound effect on the future of the mining operation. Due diligence must be exercised during the planning of a new mine and during the life of an existing mine.

The comments provided by the technical and economic assessment group of Venmyn Deloitte confirmed the need for this critical review. They found the reporting of Coal Resources in South Africa to be inconsistent. This was particularly problematic in the Waterberg Coalfield in Limpopo Province. In this coalfield there are two types of coal deposit present. The first is comprised of the thick intercalated, cyclic coal and shale/mudstone sequences of the Volksrust Formation. This overlies multiple coal seams within the Vryheid Formation, each of which is thick enough to be extracted as an individual raw coal unit. On the other hand, the interbedded coal and shale seams of the Volksrust Formation require beneficiation to separate the coal from the shale.

The review examines practices and methods, investigates alternatives, provides checks and balances, and tests these against actual production reconciliations. In conclusion, the best estimates of the mineable, in-situ tonnage will be obtained from the air-dry raw material density. These estimates should be adjusted afterwards to allow for free moisture content. The adjustments are derived from reconciliation data. The greatest contributing factor to the over-estimation of Reserve tonnages is the moisture content of the raw material. This fluctuates significantly under varying conditions in situ, as well as upon exposure to the natural environment. The air-dried density of the raw material includes inherent (structurally bound) moisture within the matrix. It provides credible tonnage estimations of raw material available while also providing an indication of voids within the volume of material being assessed. The calculated solids percentage can be used to adjust the specific gravity, which is determined via the Archimedes principle. This will supply a representative estimate of the material to be mined.

\section{Keywords}

Coal, Resource, Reserve, in-situ tonnage, density determination.

\section{Introduction}

Problems related to the reconciliation of product predictions and run-of-mine tonnages obtained from the geological model led to two major projects, initiated by the author, being undertaken at Grootegeluk Coal Mine in Limpopo Province. The initial project, 'Optimal yield prediction of semi soft coking coal and power station coal in the Waterberg Coalfield, Limpopo Province' (Roux, 2012) dealt with product prediction, actual production, and reconciliation, resulting in the determination of a beneficiation-plantspecific correlation factor applied to the predicted tonnages in order to reconcile the actual products from a specific beneficiation process. This was successful and relevant to the plant process, but did not satisfy the discrepancy between run-of-mine tonnages budgeted and those predicted from the geological model. The second project, 'The application of ash adjusted density in the evaluation of coal deposits' (Roux, 2017) addressed the discrepancy between the geological model values and actual reported run-of-mine tonnages by evaluating the whole process from exploration through the entire value chain. An assessment of the Resource material in the initial phases pertaining to exploration and laboratory processes, and various density determinations based on field and laboratory data through to run-ofmine reconciliation of mineable tons, was established. 


\section{A critical review of initial Resource and Reserve tonnage estimation and reporting}

The physical make-up and properties of the material being mined should be understood and evaluated with regard to the matrix of the raw material and the probable geological losses with reference to the raw material determined prior to establishing Resource and Reserve values. Furthermore, consideration should be given to the compatibility of the feed material with the beneficiation processes and the required products. The prediction of run-of-mine feedstock and the expected product yields should be optimal and realistically based on the mining process, the beneficiation plants, products required, and material available.

This has been accomplished by a back-to-basics evaluation, starting at the exploration phase, through core recovery, depth corrections, lithological demarcation, lithological logging of the core, profile generation, and subsequent correlation for sample delineation, sampling, and preparation prior to dispatch to accredited laboratories for analyses, and an evaluation of laboratory results. All mass derivations from the exploration field, after Archimedes SG determinations through dispatch and laboratory receipt, as well as masses determined during and after sample preparation for analysis, were evaluated and various density determination calculations done for comparative purposes. It should be noted that no effort was made to determine the moisture content on recovery or impeccably preserve the exploration drill core after recovery in the field, therefore the insitu moisture content of the core is unknown.

\section{Basic evaluation of initial core mass, volume, and density}

Drill core recovered from the core barrel is washed and laid out on $20 \mathrm{~m}$ corrugated sheeting. The core is depth-adjusted and marked off, differentiating the lithology with corresponding geophysical log data and depths for each lithology encountered. This is done to $1 \mathrm{~cm}$ accuracy. On completion of the borehole, the core is logged and described geologically, a profile of the borehole constructed, and the geological log is correlated with other boreholes from the area in order to conduct sample delineation. The samples are marked out on the core, sample depths recorded, and the core is sampled. General practises at Grootegeluk require the samples to be separated into shale and coal components, the cut off values being anything less than $1 \mathrm{~cm}$ would be left in the overriding lithology. The samples are bagged and weighed as coal and shale samples separately. Field masses for the individual

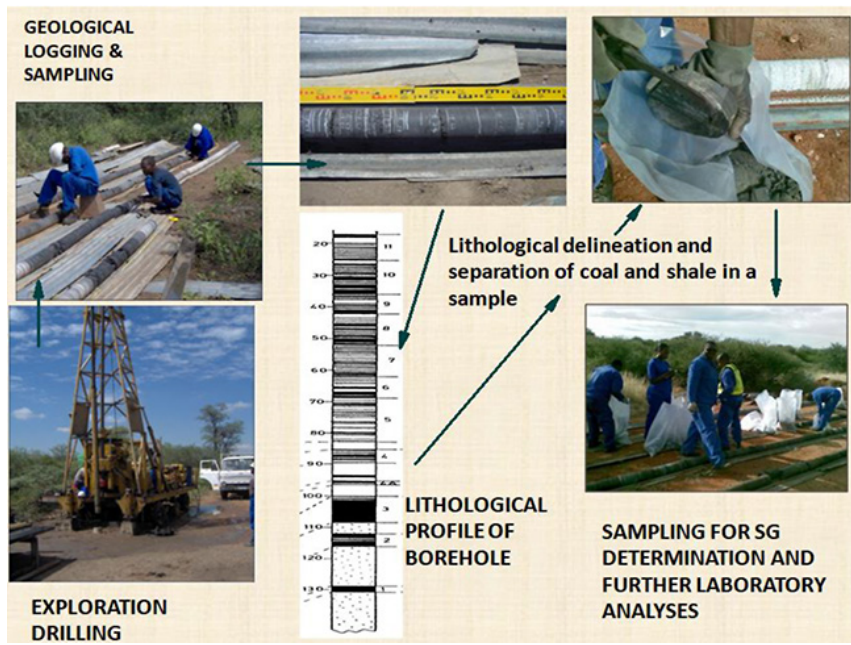

Figure 1-Pictorial flow illustrating the initial exploration phase from drilling to sampling components i.e., coal samples and shale samples are recorded since these masses would represent the received mass of the field sample in air. The samples are then subjected to SG determination via the Archimedes principle, the density derived is recorded, and a theoretical reconstruction to represent the original sample, i.e. coal and shale combined, is done to provide an SG for the entire sample. Samples are dried and re-weighed before dispatch to an accredited laboratory for analysis. Exploration core received by the laboratory is weighed on receipt, masses checked against field masses dispatched from the mine, and SG determinations done on coal and shale samples.

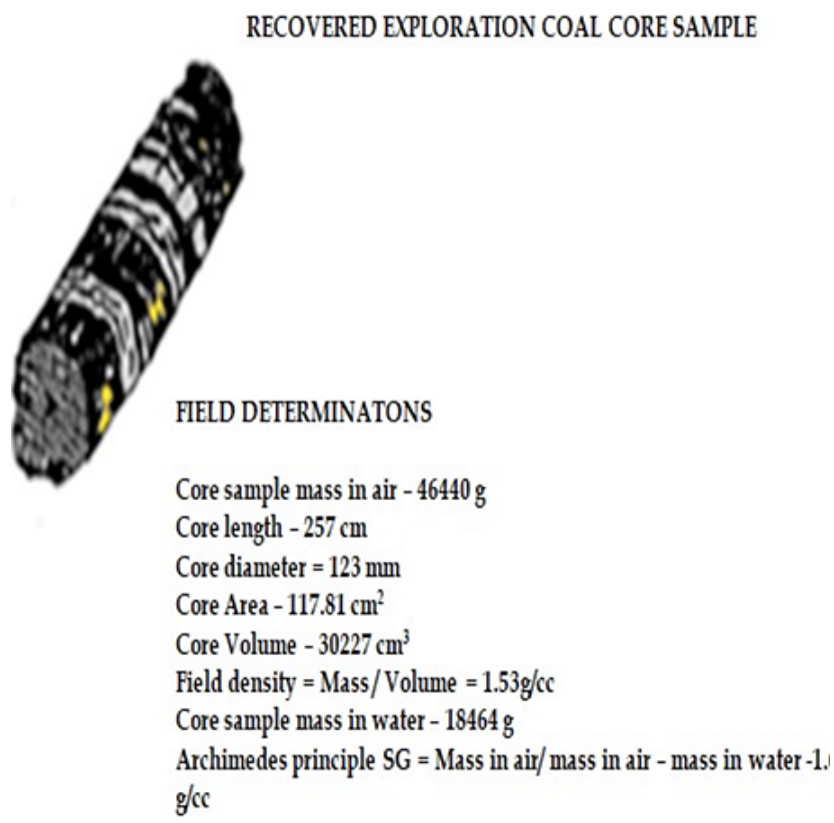

Figure 2-Coal core sample: basic field-determined density

\section{BASIC INFORMATION FROM LABORATORY PROCESSES FORSAME SAMPLE}
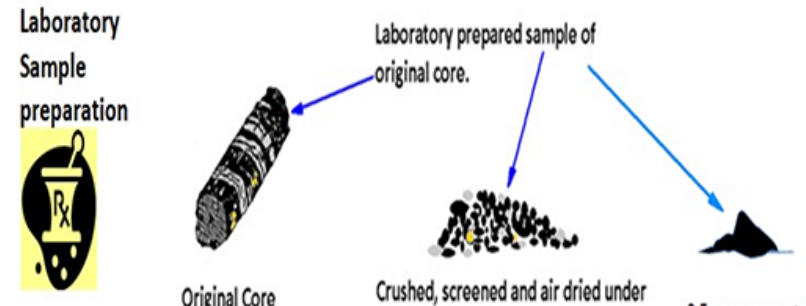

Original Core Crushed, screened and air dried under controlled temperature and humidity

$-0.5 \mathrm{~mm}$ raw material

The mass of the crushed and screened air dried products related to the envelope volume of the original core should approximate the air dry density of the sample.

\section{Initial laboratory information}

$\begin{array}{lr}\text { Core received Mass } & 46450 \mathrm{~g} \\ -13 \mathrm{~mm}+0.5 \mathrm{~mm} \text { screened Mass } 41113 \mathrm{~g} \\ -0.5 \mathrm{~mm} \text { discard Mass } \quad 2990 \mathrm{~g}\end{array}$
a) Density of core received
$1.53 \mathrm{~g} / \mathrm{cc}$
b) Density derived from $-13+0.5 \mathrm{~mm}$ material
$1.36 \mathrm{~g} / \mathrm{cc}$
c) Density derived from $-13 \mathrm{~mm}+05 \mathrm{~mm}$ and the $-0.5 \mathrm{~mm} \quad 1.46 \mathrm{~g} / \mathrm{cc}$ 


\section{A critical review of initial Resource and Reserve tonnage estimation and reporting}

Sample preparation involves crushing and screening to prescribed top sizes and screening to $-13 \mathrm{~mm}+0.5 \mathrm{~mm}$, with the $-0.5 \mathrm{~mm}$ fraction being retained for raw analysis. The crushed samples are then dried under controlled temperature and humidity conditions to represent air-dry samples, screened to $-13 \mathrm{~mm}$ and $+0.5 \mathrm{~mm}$, and re-weighed before float and sink analysis. Float /sink analysis is performed in the range from $1.35 \mathrm{~g} / \mathrm{cm}^{3}, 1.40,1.50 \ldots$ to $2.20 \mathrm{~g} / \mathrm{cm}^{3}$ for coal samples and from $1.40 \mathrm{~g} / \mathrm{cm}^{3}$ to $2.20 \mathrm{~g} / \mathrm{cm}^{3}$ for shale samples, and the yields at each float fraction determined and recorded. Thereafter proximate analyses, total sulphur, Roga Index, crucible swell number, and calorific value, as well as ash analyses on the float and sink fractions, are completed for all samples, and the results recorded and forwarded to the mine.

Figure 4 portrays an evaluation of the different density values obtained from basic field and laboratory data.

\section{Evaluation of laboratory data after float/sink and proximate analyses}

The evaluation relates to two alternative methods of obtaining accurate density determinations for the samples. The first is an ash-adjusted density algorithm derived from a regression of 31000 float and sink data-sets to obtain an accurate absolute dry density value for each float fraction within a set range of fixed density values, and adjusting these with reference to the inherent moisture content determined in the laboratory to give a credible air-dry density value for the sample. The second approach, devised by Robeck and Huo (2015), is assessing the mineral matter content and then deriving a probable in-situ density based on averaged measured moisture content. Since averaged moisture content data for the Waterberg coals was not available, the laboratory-determined inherent moisture content of the samples was used instead. Both methods were validated by pycnometerdetermined densities for the same samples. Research with regard to ash-adjusted density determined the contribution of mineral content for each fractional value from the data-set. As the mineral content increases, the ash yield content also increases, and each incremental increase represents a subtle increase in density between the previous fixed float density and the next cutoff float density.

Regression analyses based on cumulative frequencies of the various float fraction values were done on a 31000 sample

\section{An example of mass data and densities derived for the same sample portrayed below.}

\begin{tabular}{|c|c|c|c|c|c|c|c|c|c|}
\hline SAMPLE NO & \begin{tabular}{|l|} 
Lab \\
Mass \\
\end{tabular} & $\begin{array}{c}-13 \mathrm{~mm} \\
\text { Mass }\end{array}$ & $\begin{array}{c}<0.5 \mathrm{~mm} \\
\text { mass }\end{array}$ & Arch, SG & $\begin{array}{c}\text { THICKNESS } \\
(\mathrm{cm})\end{array}$ & $\begin{array}{c}\text { Core } \\
\text { Volume }\end{array}$ & \begin{tabular}{|c|} 
Field \\
mass SG
\end{tabular} & \begin{tabular}{|c|} 
Lab Mass \\
SG \\
\end{tabular} & \begin{tabular}{|c|}
$-13 \mathrm{~mm}$ \\
Mass SG \\
\end{tabular} \\
\hline 14 & 34620 & 30620 & 2387 & 1.58 & 202 & 23798 & 1.45 & 1.45 & 1.29 \\
\hline \multicolumn{2}{|l|}{$<13 \mathrm{~mm}+<0.5 \mathrm{~mm}$ Mass } & 33007 & & & & 23798 & \multicolumn{2}{|c|}{ Air Dry SG } & 1.39 \\
\hline \multicolumn{10}{|l|}{ Shale } \\
\hline SAMPLE NO & \begin{tabular}{|l|} 
Lab \\
Mass \\
\end{tabular} & $\begin{array}{c}-13 \mathrm{~mm} \\
\text { Mass }\end{array}$ & $\begin{array}{c}<0.5 \mathrm{~mm} \\
\text { mass }\end{array}$ & Arch, SG & $\begin{array}{c}\text { THICKNESS } \\
\text { (cm) }\end{array}$ & $\begin{array}{c}\text { Core } \\
\text { Volume }\end{array}$ & \begin{tabular}{|c|} 
Field \\
mass SG
\end{tabular} & \begin{tabular}{|c|} 
Lab Mas \\
SG
\end{tabular} & \begin{tabular}{|c|}
$-13 \mathrm{~mm}$ \\
Mass SG
\end{tabular} \\
\hline $14 \mathrm{~S}$ & 11654 & 10493 & 603 & 1.98 & 55 & 6480 & 1.81 & 1.80 & 1.62 \\
\hline$<13 \mathrm{~mm}+<0.5 \mathrm{~mm}$ Mass & & 11096 & & & & 6480 & Air Dr & ry SG & 1.71 \\
\hline \multicolumn{10}{|c|}{ Combined Coal and Shale $-13 \mathrm{~mm}+0.5 \mathrm{~mm}$ screened air dry material. } \\
\hline SAMPLE NO & \begin{tabular}{|l|} 
Lab \\
Mass \\
\end{tabular} & $\begin{array}{c}-13 \mathrm{~mm} \\
\text { Mass }\end{array}$ & $\begin{array}{c}<0.5 \mathrm{~mm} \\
\text { mass }\end{array}$ & Arch, SG & $\begin{array}{c}\text { THICKNESS } \\
(\mathrm{cm})\end{array}$ & $\begin{array}{c}\text { Core } \\
\text { Volume }\end{array}$ & \begin{tabular}{|c|} 
Field \\
mass SG
\end{tabular} & \begin{tabular}{|c|} 
Lab Mass \\
SG \\
\end{tabular} & \begin{tabular}{|c|}
$\begin{array}{c}13 \mathrm{~mm} \\
\text { Mass SG }\end{array}$ \\
\end{tabular} \\
\hline 14 & 46274 & 41113 & 2990 & 1.68 & 257 & 30277 & 1.53 & 1.53 & 1.36 \\
\hline \multicolumn{10}{|c|}{ Combined Coal and Shale including $-0.5 \mathrm{~mm}$ material } \\
\hline SAMPLE NO & \begin{tabular}{|l|} 
Lab \\
Mass
\end{tabular} & $\begin{array}{c}-13 \mathrm{~mm} \\
\text { Mass }\end{array}$ & $\begin{array}{c}\text { Total<.5 } \\
\text { mm } \\
\text { mass }\end{array}$ & Arch, SG & $\begin{array}{c}\text { THICKNESS } \\
\text { (cm) }\end{array}$ & $\begin{array}{c}\text { Core } \\
\text { Volume }\end{array}$ & $\begin{array}{c}\text { Field } \\
\text { mass SG }\end{array}$ & $\begin{array}{c}\text { Lab Mass } \\
\text { SG }\end{array}$ & $\begin{array}{l}\text { Air Dry } \\
\text { SG }\end{array}$ \\
\hline 14 & 46274 & \multirow{2}{*}{41113} & \multirow{2}{*}{2990} & \multirow{2}{*}{1.68} & \multirow{2}{*}{257} & \multirow{2}{*}{30277} & \multirow{2}{*}{1.53} & \multirow{2}{*}{1.53} & 1.36 \\
\hline Actual air dry Mass inlc $<.0 .5 \mathrm{~mm}$ & 44103 & & & & & & & & 1.46 \\
\hline
\end{tabular}

Figure 4-Various density values obtained from different basic methods relating to field and primary laboratory data

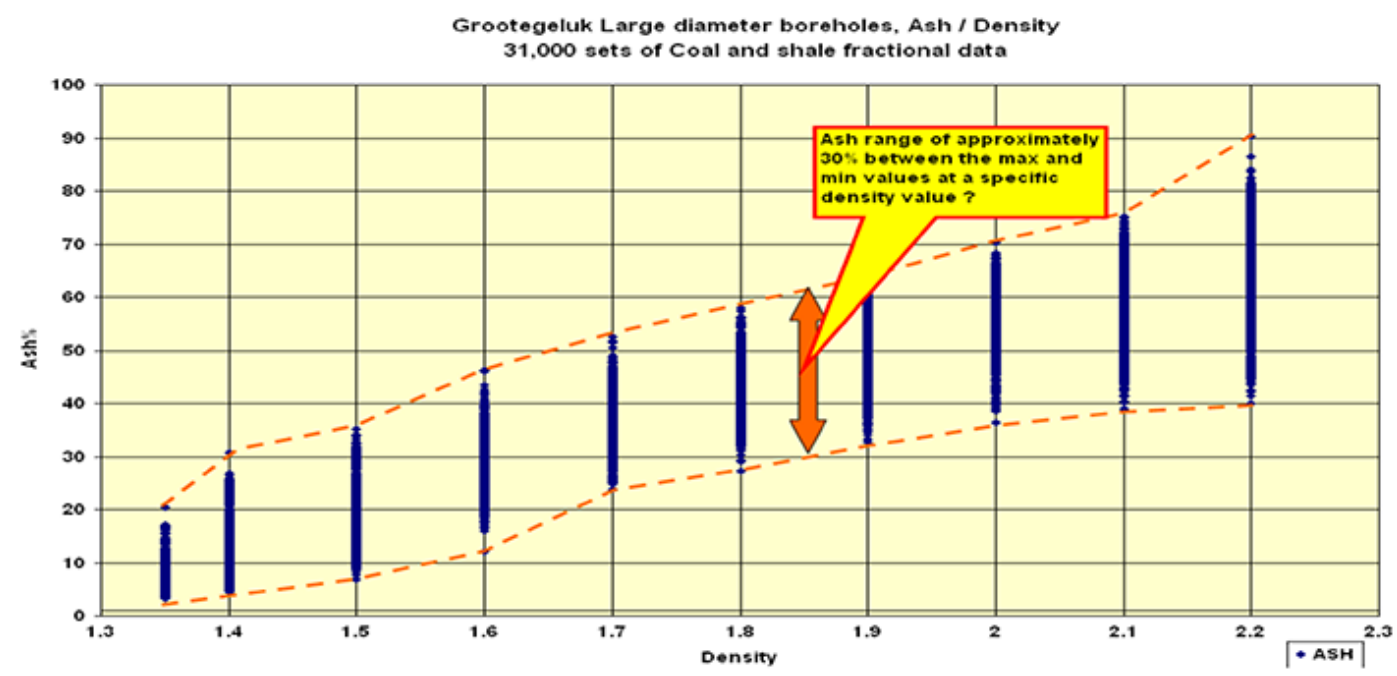

Figure 5-Distribution of ash percentage at each float density, illustrating the range of possible ash contents between float cut-offs 


\section{A critical review of initial Resource and Reserve tonnage estimation and reporting}

\section{DESCRIPTIVE STATISTIC RESULTS FOR DENSITY FLOAT FRACTIONS ASH CONTENT ANALYSES}

\begin{tabular}{|c|c|c|c|c|c|c|c|c|c|}
\hline & $\begin{array}{c}\text { Ash } \\
1,35 \mathrm{~g} / \mathrm{cc}\end{array}$ & $\begin{array}{c}\text { Ash } \\
1,40 \mathrm{~g} / \mathrm{cc}\end{array}$ & $\begin{array}{c}\text { Ash } \\
1,50 \mathrm{~g} / \mathrm{cc}\end{array}$ & $\begin{array}{c}\text { Ash } \\
1,60 \mathrm{~g} / \mathrm{cc}\end{array}$ & $\begin{array}{c}\text { Ash } \\
1,70 \mathrm{~g} / \mathrm{cc}\end{array}$ & $\begin{array}{c}\text { Ash } \\
1,80 \mathrm{~g} / \mathrm{cc}\end{array}$ & $\begin{array}{c}\text { Ash } \\
1,90 \mathrm{~g} / \mathrm{cc}\end{array}$ & $\begin{array}{c}\text { Ash } \\
2,00 \mathrm{~g} / \mathrm{cc}\end{array}$ & $\begin{array}{c}\text { Ash } \\
2,10 \mathrm{~g} / \mathrm{cc}\end{array}$ \\
\hline Mean & 7,34 & 13,51 & 20,22 & 28,48 & 35,96 & 42,32 & 48,15 & 53,32 & 57,08 \\
\hline Standard error & 0,05 & 0,08 & 0,09 & 0,10 & 0,09 & 0,09 & 0,10 & 0,10 & 0,12 \\
\hline Median & 6,99 & 14,06 & 21,00 & 29,20 & 36,41 & 42,61 & 48,60 & 53,70 & 57,67 \\
\hline Mode & 6,10 & 16,00 & 21,70 & 29,90 & 37,60 & 44,00 & 51,00 & 52,70 & 59,10 \\
\hline Standard Deviation & 2,09 & 3,62 & 4,14 & 4,23 & 4,14 & 4,16 & 4,33 & 4,48 & 5,12 \\
\hline Sample Variance & 4,36 & 13,07 & 17,14 & 17,89 & 17,16 & 17,29 & 18,77 & 20,09 & 26,22 \\
\hline Kurtosis & 3,03 & 0,52 & 0,14 & $-0,23$ & $-0,30$ & $-0,19$ & 0,04 & 0,36 & 0,12 \\
\hline Skewness & 1,29 & 0,17 & $-0,31$ & $-0,26$ & $-0,13$ & $-0,15$ & $-0,38$ & $-0,46$ & $-0,50$ \\
\hline Range & 17,22 & 26,23 & 25,40 & 27,50 & 27,96 & 30,70 & 29,10 & 31,80 & 31,61 \\
\hline Minimum & 3,28 & 4,47 & 8,70 & 15,90 & 23,74 & 27,20 & 32,70 & 36,30 & 39,09 \\
\hline Maximum & 20,50 & 30,70 & 34,10 & 43,40 & 51,70 & 57,90 & 61,80 & 68,10 & 70,70 \\
\hline Sum & 14156,60 & 26103,04 & 39170,81 & 55259,82 & 69800,52 & 82064,53 & 92059,22 & 100987,23 & 107816,41 \\
\hline Count & 1928 & 1932 & 1937 & 1940 & 1941 & 1939 & 1912 & 1894 & 1889 \\
\hline 95\% Confidence Leve & 0,09 & 0,16 & 0,18 & 0,19 & 0,18 & 0,19 & 0,19 & 0,20 & 0,23 \\
\hline
\end{tabular}

Coal values from descriptive statistics based on original data-set used for AAD evaluation

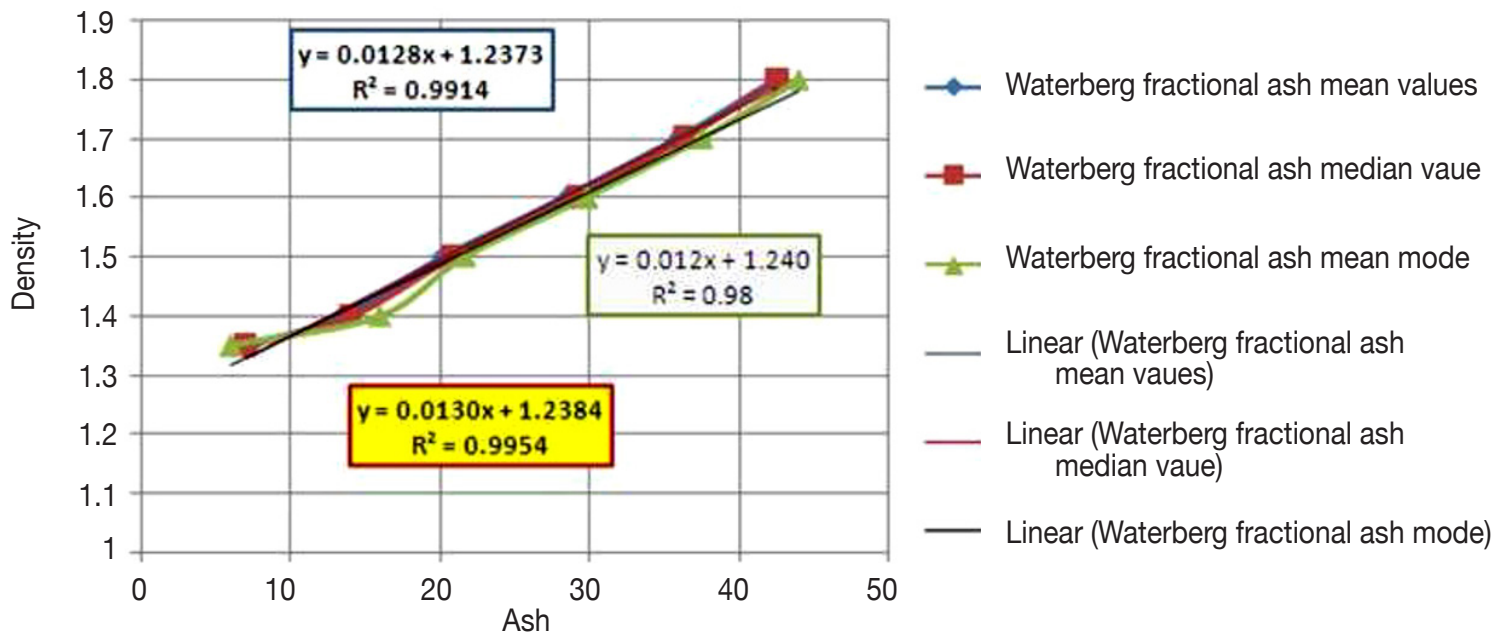

Figure 6-Descriptive statistics results and plots of the linear regressions on mean, median, and mode

data-set (Roux, 2012) and later refined through statistical methods to produce the algorithm eventually applied. The ashdensity relationship displays the distribution around specific float densities and can be accommodated along the slope of increasing ash with increasing density (Roux, 2017).

The linear regression done on median values from descriptive statistics provided the following relationship:

$$
\mathrm{RD}=(0.013 \times \mathrm{Ash} \%)+1.238
$$

which also resulted in an $\mathrm{R} 2$ value of 0.99 . The constant 1.238 represents the density of bituminous coal. The credibility of the densities obtained was questioned; this led to a request that each fraction from samples in a new exploration borehole be subjected to pycnometry by the density bottle method (Australian Standard method AS1038.21 Item 4) to determine the densities of the individual fractions from the samples. A total of 741 'true relative densities' for float and sink fractions were determined according to this method. The coal and shale samples combined for the separate stratigraphic units, ash-adjusted density (AAD)derived densities, and the re-determined laboratory densities were compared and statistically evaluated at a 99.9\% confidence level. The differences between $\mathrm{AAD}$ and pycnometer-derived densities are illustrated in Figure 7 . The AAD values had not been corrected to accommodate the inherent moisture content, thus they represent an absolute dry matrix density, and if this correction is applied the values would be comparable with an airdry density.

All three sets of values obtained at various confidence levels indicate a high level of accuracy. The evaluation based on a comparison between AAD-calculated values and laboratorydetermined values indicates that the AAD methodology can be used confidently for predictions of dry densities in coal assessments. Minor differences between the two data-sets (AAD and pycnometer) are attributable to the inherent moisture content of the samples.

Robeck and Huo (2015), however, used another approach to ascertain in-situ density. Their study did not support the ash content as a basis for the evaluation of density since they believed that ash was a product of combustion and that inorganic volatiles would have contributed more to the losses through combustion. Their method is referred to as the Gray method.

The proposed evaluation requires an estimation of mineral matter content. The most commonly used approach is the Parr formula (Rees, 1966):

$$
M d=1.08 \text { Ad }+0.55 \text { Stot }
$$

where Stot $=$ total sulphur (dry)

and the mineral matter ratio is determined by 


\section{A critical review of initial Resource and Reserve tonnage estimation and reporting}

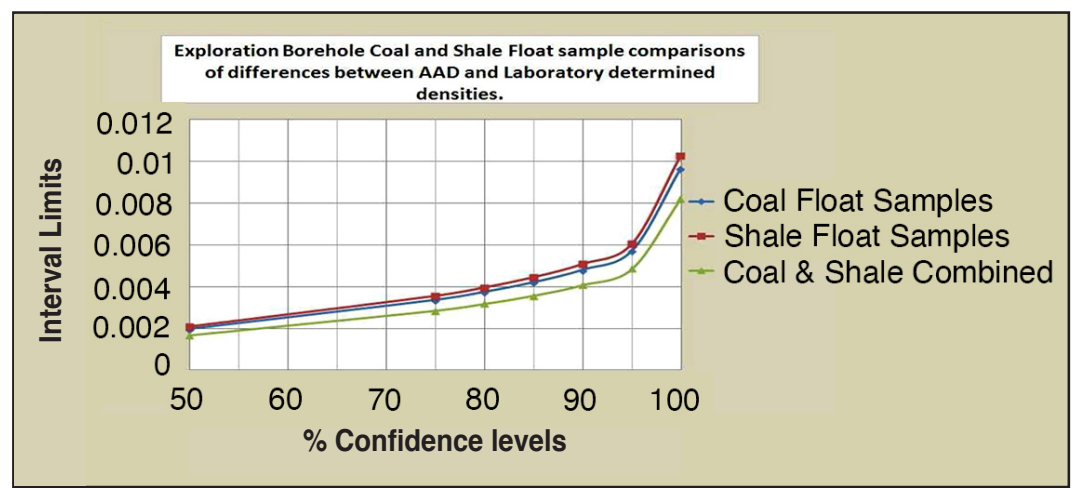

Figure 7-Differences between AAD predicted values and pycnometer-determined RD at various confidence levels, the combined coal and shale samples showing the lowest difference up to a $95 \%$ confidence level. This is smaller than 0.005

$$
r=\frac{1.08 A d+0.55 \text { Stot }}{A d} \text {. }
$$

The Gray method, in which Md cannot exceed $100 \%$, accounts for a wider range of mineral volatiles and reveals changes in mineral content with increasing ash. This only requires specific energy $(\mathrm{CV})$ and ash, and is the most robust method, particularly for high-ash samples. The relationship between dry $\mathrm{CV}$ and mineral matter is given by:

$$
E d=E d m m f \frac{100-M d}{100}
$$

where $E d=$ Specific energy, dry expressed in $M J / k g$ $E d m m f=$ Specific energy, dry mineral matter-free and the mineral matter ratio is determined by

$$
r=\frac{100(E d m m f-E d)}{E d m m f A d}
$$

The dry mineral matter-free $\mathrm{CV}$ is determined by:

$$
E d m m f=\frac{100 *(C V-0.15 S)}{(100 *(\operatorname{Minh}+1.08) *(A d+0.55 S))}
$$

Mineral matter content is then derived by:

$$
M d=r A d
$$

(for all samples).

The determination of the air-dry density of the sample is then obtained from the equation:

$$
\text { pest }=\frac{100}{(a+b) * M d}
$$

where coefficients $a$ and $b$ are determined by:

$$
a=\left(\frac{\text { Minh }}{\rho w}\right)+\left(100-\frac{\text { Minh }}{\rho c}\right)
$$

where $\rho c$ represents the matrix density of bituminous coal $\left(1.2384 \mathrm{~g} / \mathrm{cm}^{3}\right)$ and $\rho w$ is the density of water at $5^{\circ} \mathrm{C}\left(1.0 \mathrm{~g} / \mathrm{cm}^{3}\right)$.

$$
b=\left(100-\frac{M i n h}{100}\right) *\left(\frac{\rho c-\rho m}{\rho c * \rho m}\right)
$$

where $\rho m=$ density of the mineral matter. Here, $2.53 \mathrm{~g} / \mathrm{cm}^{3}$ was used for Waterberg coals.

The individual sample densities can then be obtained from the following equations:

$$
\begin{aligned}
& \rho c=\frac{100}{a} \\
& \text { and } \\
& \rho m=\frac{100}{a+(100 * b)}
\end{aligned}
$$

The values determined from the AAD and Gray methods represent air-dry densities. The AAD values have been adjusted from an absolute dry (moisture-free) basis to an air-dry basis, including the analytical inherent moisture (\%) so that all three data-sets are comparable. Note that the matrix density of bituminous coal at $1.2384 \mathrm{~g} / \mathrm{cm}^{3}$ and that of the mineral content at $2.53 \mathrm{~g} / \mathrm{cm}^{3}$ were the same as the values used in the AAD evaluation and have been used in the Gray method. Trends established by the AAD and Gray methods correlate almost perfectly, with a slight divergence in the higher ash regimes (Figure 8).

The assessment and tabulation of field, preliminary laboratory, and proximate analysis calculated values for the sample used in the example, which were obtained for density determinations, are illustrated in Table I. From the foregoing, very little difference is apparent between the methods utilizing the analytical data. Densities of 1.45 to $1.46 \mathrm{~g} / \mathrm{cm}^{3}$ were obtained using an average correction factor of 0.83 for the solid matrix, which implies that the effective porosity of this sample is approximately $17 \%$. In Table II the overestimation is determined by the final percentage by which the calculated value exceeds the mass of the measured air-dry material, i.e. the Archimedescalculated mass of $50865 \mathrm{~g}$ measured against $44204 \mathrm{~g}$ results in an overestimation of approximately $15.06 \%$. It is also apparent that the original field mass volume contains a fair percentage of moisture.

\section{Reconciliation of actual production results, validating the foregoing with regard to basic Resource and Reserve tonnage estimations}

From a mining production and reconciliation perspective two examples, one from the Volksrust Formation and the second from the Vryheid formation, were dealt with. These two scenarios are depicted in the locality map in Figure 9, showing the positions of the mining strips, blocks, and surrounding exploration boreholes from which the basic information with regard to mining block densities and expected run-of-mine tonnages were obtained. The same approach using the basic density equation was used in this 


\section{A critical review of initial Resource and Reserve tonnage estimation and reporting}

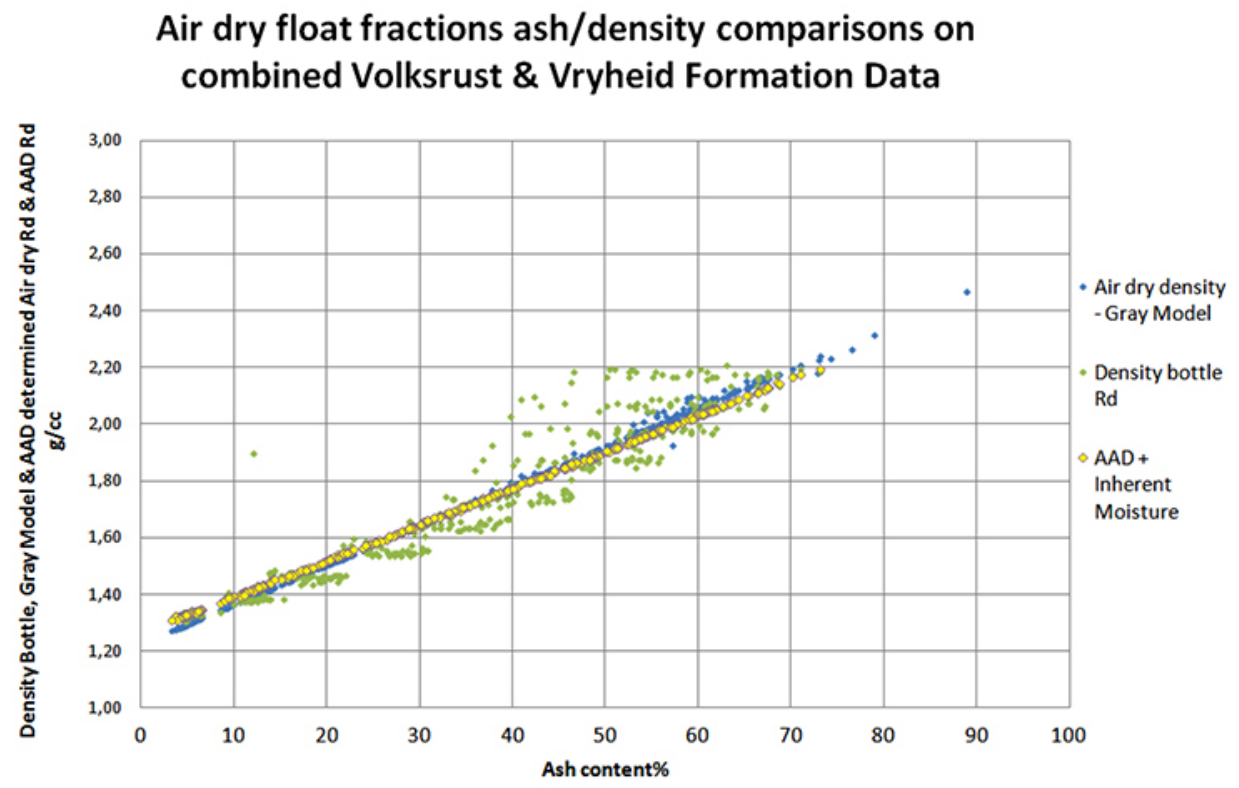

Figure 8-Plot of inherent moisture-adjusted AAD RD, Gray Method RD, and laboratory density-bottle-RD

Table I

Summary of derived densities using various methods of determination. Combined coal and shale

\begin{tabular}{|c|c|c|c|c|c|c|}
\hline Determination method & $\begin{array}{l}\text { Mass } \\
\mathrm{g}\end{array}$ & $\begin{array}{l}\text { Volume } \\
\mathrm{cm}^{3}\end{array}$ & $\begin{array}{l}\text { Density } \\
\mathrm{g} / \mathrm{cm}^{3}\end{array}$ & $\begin{array}{l}\text { Perceived } \% \\
\text { solids }\end{array}$ & $\begin{array}{l}\text { Possible } \% \\
\text { voids }\end{array}$ & $\begin{array}{l}\text { Mass loss from original field } \\
\text { mass to other measured masses }\end{array}$ \\
\hline \multicolumn{7}{|c|}{ Field and preliminary laboratory evaluation of perceived solids and voids } \\
\hline Archimeded & 46300 & 27560 & 1.68 & 0.91 & 0.09 & \\
\hline Field mass/volume & 46300 & \multirow{2}{*}{30277} & 1.529 & & & \\
\hline Lab mass./volume & 46274 & & 1.528 & & & \multirow[t]{2}{*}{26} \\
\hline Determination method & Mass $\mathrm{g}$ & Volume $\mathrm{cm}^{3}$ & RD & $\begin{array}{l}\% \text { Solids } \\
\text { matrix }\end{array}$ & $\begin{array}{l}\text { Possible } \% \\
\text { voids }\end{array}$ & \\
\hline \multicolumn{7}{|c|}{ Laboratory sample preparation evaluation of perceived solids and voids } \\
\hline$-13 \mathrm{~mm}-0.5 \mathrm{~mm}$ mass/volume & 41113 & \multirow{2}{*}{30277} & 1.358 & 0.81 & 0.19 & 5187 \\
\hline Air dry mass including $<0.5 \mathrm{~mm} / \mathrm{volume}$ & 44103 & & 1.46 & 0.87 & 0.13 & 2197 \\
\hline Determination method & Mass $\mathrm{g}$ & Volume $\mathrm{cm}^{3}$ & RD & $\begin{array}{l}\% \text { Solids } \\
\text { matrix }\end{array}$ & $\begin{array}{l}\text { Possible } \% \\
\text { voids }\end{array}$ & $\begin{array}{c}\text { Air-dry RD derived from RD } \\
x \% \text { solid matrix }\end{array}$ \\
\hline \multicolumn{7}{|c|}{ Validation of solid matric RD based on pycnometer, AAD results and grey method } \\
\hline Pycnometer RD & \multirow{4}{*}{44103} & \multirow{4}{*}{25347} & 1.74 & 0.84 & 0.16 & 1.457 \\
\hline Absolute dry AAd RD & & & 1.72 & 0.85 & 0.15 & 1.457 \\
\hline Air dry AAD RD & & & 1.76 & 0.83 & 0.17 & 1.457 \\
\hline Gray method RD & & & 1.75 & 0.83 & 0.17 & 1.460 \\
\hline
\end{tabular}

Table II

Overestimation of core mass as a result of solid to void ratios

\begin{tabular}{|c|c|c|c|c|c|c|}
\hline Determination method & $\begin{array}{l}\text { Density } \\
\mathrm{g} / \mathrm{cm}^{3}\end{array}$ & $\begin{array}{l}\text { Volume } \\
\mathrm{cm}^{3}\end{array}$ & $\begin{array}{l}\text { Actual solids } \\
\text { volume } \mathrm{cm}^{3}\end{array}$ & $\begin{array}{l}\text { Voids } \\
\text { volume } \mathrm{cm}^{3}\end{array}$ & $\begin{array}{c}\% \\
\text { voids }\end{array}$ & \\
\hline Air dry mass including $<0.5 \mathrm{~mm} /$ volume & 1.46 & \multirow{5}{*}{30277} & 25251 & 5026 & $16.60 \%$ & $\begin{array}{c}\text { Based on average calc values from } \\
\text { pycnometer, AAD and Gray methods. RD }\end{array}$ \\
\hline Pycnometer RD & 1.74 & & 25347 & 4930 & $16.28 \%$ & \\
\hline Air dry AAD RD & 1.76 & & 25130 & 5147 & $17.00 \%$ & \\
\hline Gray method RD & 1.75 & & 25130 & 5147 & $17.00 \%$ & \\
\hline Average for calculated values & 1.75 & & 25130 & 5147 & $17.00 \%$ & \\
\hline Determination method & $\begin{array}{c}\text { Density } \\
\mathrm{g} / \mathrm{cm}^{3}\end{array}$ & $\begin{array}{c}\text { Volume } \\
\text { cc }\end{array}$ & $\begin{array}{l}\text { Mass in grams }= \\
\mathrm{RD} \times \text { volume }\end{array}$ & $\begin{array}{c}\% \text { Over } \\
\text { estimation }\end{array}$ & & \\
\hline Archimedes & 1.68 & \multirow{2}{*}{30277} & 50865.36 & $15.07 \%$ & & \\
\hline Air dry mass including $<0.5 \mathrm{~mm} /$ volume & 1.46 & & 44204.42 & & & \\
\hline
\end{tabular}




\section{A critical review of initial Resource and Reserve tonnage estimation and reporting}

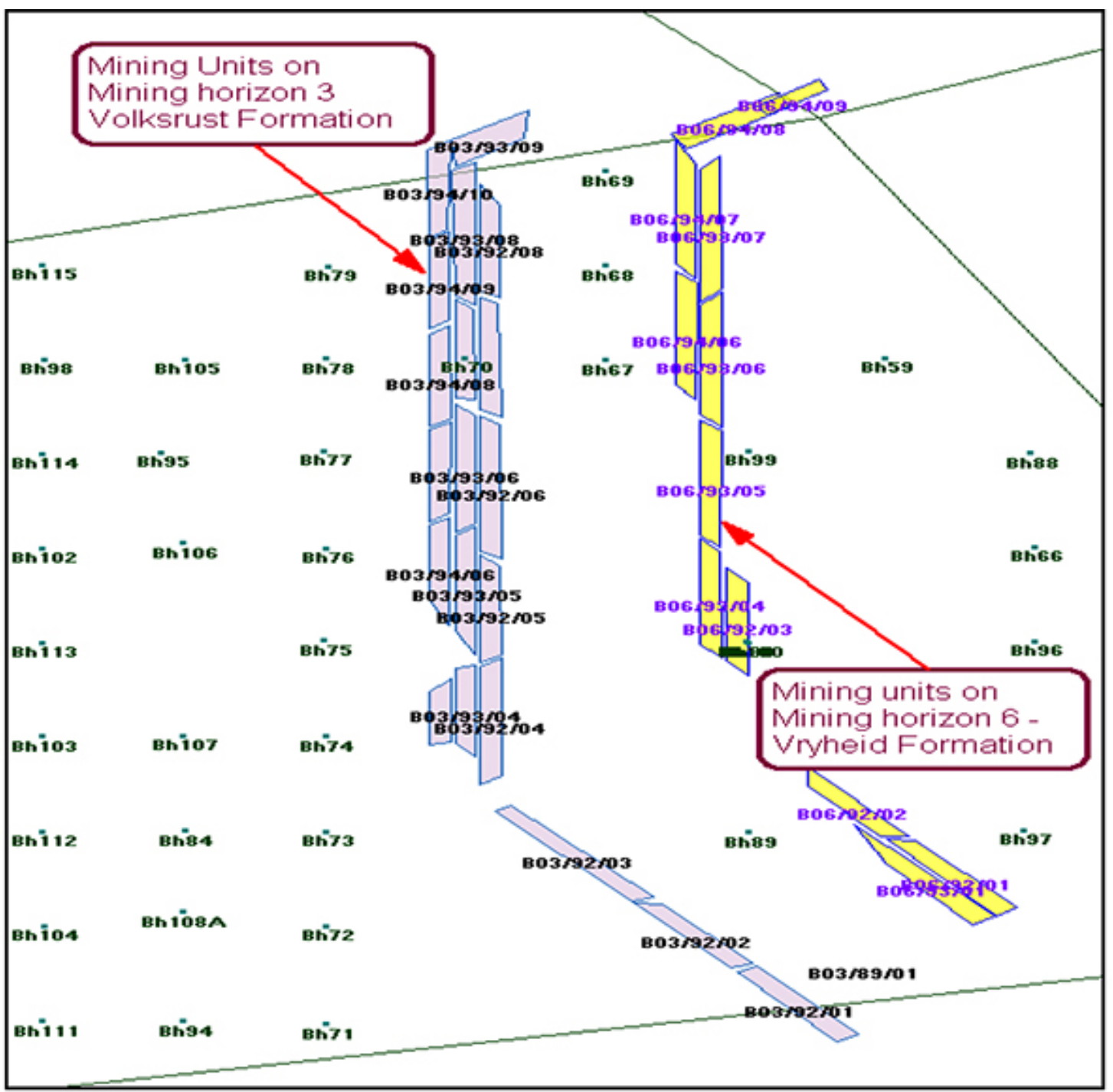

Figure 9-Locality map illustrating the respective mining strips, mining units, and mining horizons evaluated, with locations of boreholes over the entire area

evaluation. The masses relate to tonnages, the volumes in cubic metres to the material mined, and the initial densities allocated to the areas as well as the derived densities represented by the surveyed volumes and reported tonnages. Differences between the Volksrust Formation and the Vryheid Formation are depicted in Figure 10.

Two uniquely different types of deposit are represented by the mining horizons used in this reconciliation exercise. Mining horizon 3 in the Volksrust Formation represents a thick interbedded coal seam deposit, which includes coal and shale and requires beneficiation to separate the two main lithologies. The shales could be regarded as a contaminant but they need to be mined together, thus would constitute the raw reserve with respect to mineable run-of-mine tonnages. Mining horizon 6 in the Vryheid Formation, however, is classified as part of a multiple seam deposit; the coal portion can be extracted without beneficiation and can thus be considered as an in-situ Reserve.

Table III represents summaries of the weighted averages for the four data-sets relevant to the mining horizon 3 units, depicting tonnage differences and overestimation percentages.

In Table III, overestimation percentages are attributable to completely different areas, bench thicknesses, densities, and volumes planned and staked as opposed to the raw material actually mined. The most important difference, however, lies between the as-mined data and the surveyed data. In Table IV the areas, volumes, bench thicknesses, and relative densities for the model, staked, and as-mined scenarios have been equalized in order to compare the four scenarios on the same basis, the only difference being the tonnage for the surveyed material and its resultant density. This shows a difference of $17.41 \%$, which could be attributable to the voids in the matrix, which implies that the solid matrix contributes only $82.59 \%$ to the final density.

In Table $\mathrm{V}$ the areas, bench thicknesses, and in-situ tons derived from raw density data are compared with surveyed areas and derived tonnages as well as dispatch values of tonnages sent to beneficiation plants. The dispatched tonnage divided by the surveyed tonnage show a loss of $17.89 \%$, which may be indicative of voids in the original raw material which had not been taken into account in a geological loss factor. The actual density of the material dispatched to the various plants was $1.35 \mathrm{~g} / \mathrm{cm}^{3}$, as opposed to the $1.65 \mathrm{~g} / \mathrm{cm}^{3}$ used for planning or raw density for these blocks.

Finally, both the theoretical values obtained from a sample used illustratively and the reconciliation data pertaining to far 


\section{A critical review of initial Resource and Reserve tonnage estimation and reporting}

\section{MINING HORIZON 3 TYPE DEPOSIT}

GENERALIZED STRATIGAPHIC COLUMN OF A THICK INTERBEDDED COAL SEAM TYPE DEPOSIT, THE VOLKSRUST FORMATION IN THE WATERBERG COALFIELDS

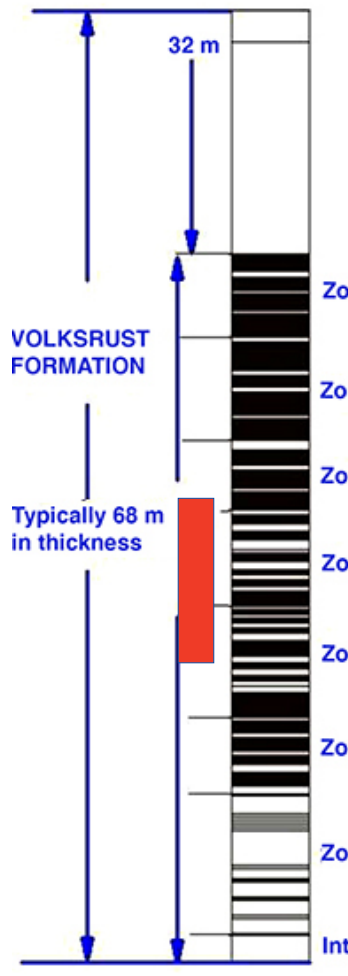

Soil/weathered

Mudstone yellow - brown, weathered in upper half, massive, light grey mudstone in lower half.

Bright coal intercalated

Zone 11 with grey mudstone, carbonate lenses

Bright coal intercalated with carbonaceous shale/mudstone, minor siderite, carbonate lenses, thick coal bands in lower half

Bright coal with prominent siderite occurrences at base, intercalated with carbonaceous shale/ mudstone, thick coal band in lower half

Bright coal with prominent siderite occurrences at base, intercalated with carbonaceous shale/ mudstone. Thick coal band at base

Bright coal, very sideritic throughout, intercalated as numerous thin bands with carbonaceous shale/mudstone. Prominent siderite at base

Bright coal, very sideritic in lower half, intercalated as numerous thin bands with carbonaceous shale/ mudstone

Carbonaceous shale/mudstone with thin coal bands in lower two thirds, siderite less prominent, and approximately $2.5 \mathrm{~m}$ carbonaceous mudstone to coaly shale at base

Interbeds Carbonaceous shale/mudstone, dark grey

\section{MINING HORIZON 6 TYPE DEPOSIT}

GENERALIZED STRATIGRAPHIC SEQUENCE FOR MULTIPLE SEAM TYPE DEPOSIT IN THE WATERBERG COALFIELD. VRYHEID FORMATION

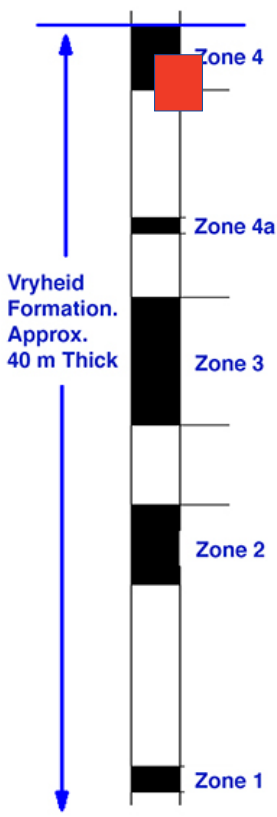

Carbonaceous shale/mudstone

dark grey

Interburden - Mudstoned

dark grey to black.

Fossiliferous Siltstone at

base

Mudstone dark grey

Sandstone, medium to coarse grained, ew thin shale bands, thin coal bands near top

Sandstone, medium to coarse grainded with a few interspersed thin coal and silstone bands

Figure 10-Waterberg coal deposit types, relating to the Volksrust Formation (left) and the Vryheid Formation (right)

Table III

Mining Horizon 3 in the Volksrust Formation

\begin{tabular}{|l|c|c|c|c|c|}
\hline \multirow{2}{*}{} & \multicolumn{5}{|c|}{ Summary of initial reported values } \\
\cline { 2 - 6 } & Area & Thick & RD & Volume & Tonnage \\
\hline Model & 220414.00 & 15.84 & 1.85 & 3491357.76 & 6459011.86 \\
Staked & 225836.00 & 16.02 & 1.85 & 3617892.72 & 6693101.53 \\
As mined & 150858.00 & 16.14 & 1.86 & 2434848.12 & 4522987.95 \\
Surveyed & 149998.00 & 16.23 & 1.53 & 2434125.76 & 3719131.91 \\
\hline Model to surveyed tonnage difference & 2739879.95 \\
Model \% overestimation & & 2973969.63 \\
\hline Staked to surveyed tonnage difference & & $44.43 \%$ \\
Staked \% overestimiation & & & 803856.04 \\
\hline A-mined tonnage difference & & $17.77 \%$ \\
\hline As-mined \% overestimation
\end{tabular}

larger mining blocks, which in the case of mining horizon 3 comprise several samples in the vertical sequence and mining horizon 6, which is purportedly a relatively pure dull coal bench, have exhibited voids in the range of $16 \%$ to $>17 \%$.

\section{Discussion}

The initial requirement in the SAMREC Code pertains to an insitu density of the resource material for tonnage estimations of 'mineable tonnes in situ'. The term in-situ requires the inclusion of all the matrix components, i.e. the solid matrix, moisture, voids, or gases contained within the matrix in order to ascertain
Table IV

Comparison of planning, survey, and mining data-sets on the same basis

\begin{tabular}{|l|c|c|c|c|c|}
\hline \multirow{2}{*}{} & \multicolumn{5}{|c|}{ Calculated values for surveyed area and volume } \\
\cline { 2 - 6 } & Area & Thick & RD & Volume & Tonnage \\
\hline Model & 149998.33 & 16.23 & 1.85 & 2434125.76 & 4503132.66 \\
Staked & 149998.33 & 16.23 & 1.85 & 2434125.76 & 4503132.66 \\
As mined & 149998.33 & 16.23 & 1.85 & 2434125.76 & 4503132.66 \\
Surveyed & 149998.33 & 16.23 & 1.53 & 2434125.76 & 3719131.90 \\
\hline As-mined tonnage difference & & 784000.76 \\
As-mined \% overestimation
\end{tabular}

the tonnages of the raw material in its natural in-situ state. SAMREC should specify that tonnes in-situ must be reported on an air-dry basis.

Groundwater levels, porosity, and permeability would greatly influence the in-situ density of the material being assessed. By implication this requires exploration core to be impeccably preserved on recovery so that the adventitious moisture content may be accurately determined in the laboratory. Consider the two scenarios in Figure 11. In the first, illustrating an exploration borehole intersecting a coal sequence below the groundwater table, the probability of the core retaining the moisture is relatively good, provided that it is impeccably preserved on recovery. In the second example, a purported dry borehole, the core may still contain some moisture, relating initially to 


\section{A critical review of initial Resource and Reserve tonnage estimation and reporting}

Table $V$

Bench 6 blocks with as-mined reported values as well as the final survey results

\begin{tabular}{|c|c|c|c|c|c|c|c|c|c|c|}
\hline \multirow[t]{2}{*}{ Block No. } & \multicolumn{3}{|c|}{ As-mined reported dats } & \multicolumn{2}{|l|}{ Model } & \multicolumn{2}{|c|}{ Survey measured data } & \multicolumn{3}{|c|}{ Dispatch reported tonnages } \\
\hline & Seam & $\begin{array}{l}\text { As-mined } \\
\text { area }\end{array}$ & $\begin{array}{l}\text { As-mined } \\
\text { bench thick }\end{array}$ & $\begin{array}{l}\text { Equivalent as-mined } \\
\text { in-situ tons }\end{array}$ & $\begin{array}{l}\text { Archimedes } \\
\text { raw RD }\end{array}$ & $\begin{array}{l}\text { Surveyed } \\
\text { volume }\end{array}$ & $\begin{array}{l}\text { Surveyed } \\
\text { tons }\end{array}$ & GG3 & GG2 & $\begin{array}{l}\text { Toal despatch } \\
\text { tons }\end{array}$ \\
\hline B06/92/01 & Bench 6 & 12049 & 3.51 & 70614 & 1.67 & 42284 & 70614 & 109727 & 489 & 110217 \\
\hline B06/92/02 & & 10926 & 3.92 & 70614 & 1.65 & 42797 & 70614 & 82095 & 1309 & 83404 \\
\hline B06/92/03 & & 3256 & 2.70 & 14520 & 1.65 & 8800 & 14520 & 91196 & 1476 & 92672 \\
\hline B06/93/01 & & 31934 & 3.56 & 188867 & 1.66 & 113775 & 188867 & 56746 & 813 & 57559 \\
\hline B06/93/04 & & 15018 & 3.18 & 78417 & 1.64 & 47815 & 77938 & 57176 & 1151 & 58328 \\
\hline B06/93/05 & & 10751 & 3.47 & 61108 & 1.64 & 37261 & 61108 & 70092 & 1633 & 71725 \\
\hline B06/93/06 & & 36800 & 2.85 & 169828 & 1.62 & 104832 & 169828 & 75194 & 661 & 75855 \\
\hline B06/93/07 & & 15273 & 3.10 & 77246 & 1.63 & 47390 & 77246 & 77423 & 1194 & 78616 \\
\hline B06/93/08 & & 1241 & 3.20 & 6501 & 1.64 & 3964 & 6501 & 100049 & 1194 & 101242 \\
\hline B06/94/06 & & 69319 & 2.26 & 255861 & 1.63 & 156970 & 255861 & 51522 & 3447 & 54968 \\
\hline B06/94/07 & & 5791 & 2.82 & 26621 & 1.63 & 16332 & 26621 & 51522 & 1799 & 53321 \\
\hline
\end{tabular}

\section{Table VI}

\section{Comparison of planning, survey, and mining data-sets}

\begin{tabular}{|l|c|c|c|c|c|}
\hline \multirow{2}{*}{} & \multicolumn{5}{|c|}{ Summary of reported values } \\
\cline { 2 - 6 } & Area & Thick & RD & Volume & Tonnage \\
\hline Model & 158054 & 4.05 & 1.64 & 639506 & 1048724 \\
Staked & 155235 & 3.73 & 1.64 & 578373 & 947705 \\
As mined & 212357 & 2.93 & 1.64 & 622220 & 1020196 \\
Surveyed & 212362 & 2.93 & 1.64 & 622220 & 1019718 \\
Dispatch & 212362 & 2.93 & 1.35 & 622220 & 837908 \\
\hline Probable voides & $17.89 \%$ & & \\
\hline
\end{tabular}

interstitially trapped water, to structural or inherent moisture, or moisture introduced during drilling. These values should also be ascertained since they will influence the overall apparent relative density of the material.

Another aspect to be taken into consideration relates to the time elapsed and possible changes to the in-situ environment between the exploration phase and actual mining of the deposit.

Consider an exploration borehole that may have been drilled several years earlier, prior to any mining activities, but is now in a position where an opencast mining operation has advanced closer to the borehole, on which the original determinations were done Groundwater has drained from this area into the mine's sump over the years and is now at a level below some of the coal seams, and the mining benches have been exposed to the ambient atmospheric and climatic conditions for several years, thus rendering them effectively dry. Information with regard to in-situ densities determined during the exploration phase and used for mineable tons in-situ determinations will no longer be valid since the moisture content in the subsurface environment has changed over time. If, however, the densities were determined on an air-dry basis initially, the reference base and subsequent changes in moisture content or water content will have no influence.

What would the in-situ moisture content of this material be? Assuming this is the same borehole as shown in the first scenario (Figure 11), the moisture content in the upper benches may be the same as for the borehole drilled through a dry area, similar to the one shown in the second scenario. Surely it is no longer feasible to use the values initially obtained for an in-situ density, especially if they were derived using the Archimedes principle method? The most logical value to use would be representative of the air-dry relative density, which at least partially conforms to the material being mined. This value would allow more credible Resource and Reserve tonnage estimations and an improved planned volume of material to be extracted in order to satisfy budgetary predictions.

\section{Conclusions}

$>$ An intimate knowledge of the physical nature of the matrix is a prerequisite, since porosity of the matrix components contributes to the complexity.

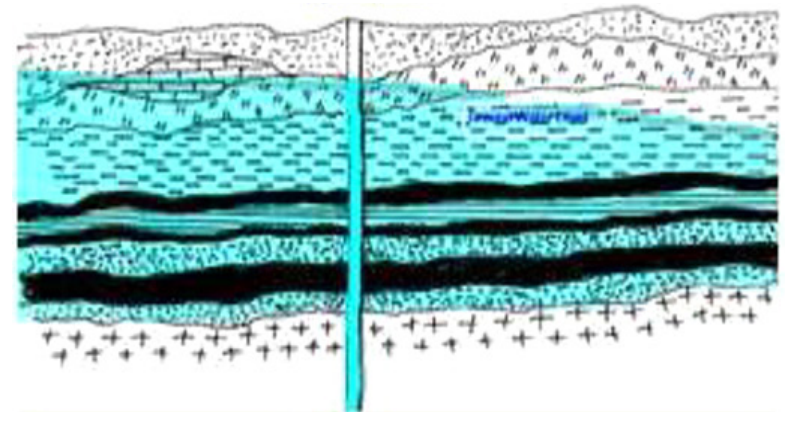

Scenarion 1 Coal measures below groundwater level

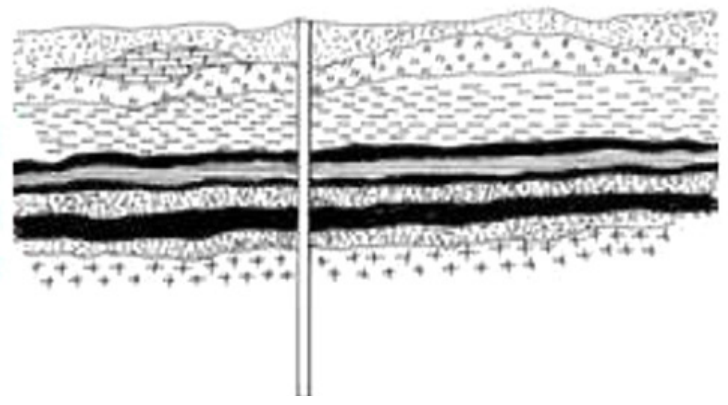

Scenarion 2 Essentially dry- no groundwater influence

Figure 11-Two exploration scenarios 


\section{A critical review of initial Resource and Reserve tonnage estimation and reporting}

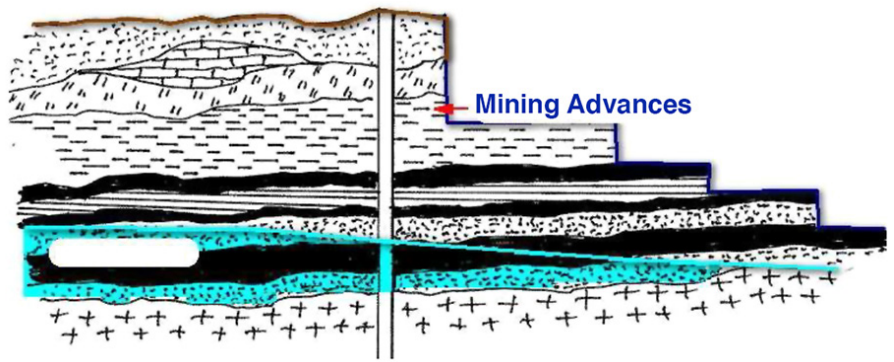

Scenarion 3 Opencast mining approaches the exploration borehole illustrating the effect of the drainage of ground water over time

Figure 12-Effect of groundwater drainage over time

> Neither the Archimedes-determined SG nor RD determined by pycnometry are suitable for in-situ Resource tonnage estimation unless the samples were impeccably preserved and the moisture content determined.

> An idea of moisture content at the time of the Archimedes determination can be formulated by determining the volume required to support the derived SG. The difference between the initial volume and the determined volume would be indicative of the moisture content at that time.

> Pycnometer density would also require a reconstruction of the sample to its original state with regard to the initial volume of the sample.

- The air-dried, crushed, and screened masses reconstituted can be used with the original sample volume to give a representative air-dry RD.

> The representative air-dry RD value can be validated by utilizing both the AAD methodology and the Gray method, substituting the inherent moisture content. The AAD method would give an absolute dry density, which would then be adjusted by the inherent moisture content to provide an air-dry RD.

- This RD does not represent the in-situ RD but gives an accurate value for the matrix material to be recovered.

> The in-situ RD is applicable only when densities are determined immediately before mining, due to the changing environments with regard to the movement of groundwater and the time elapsed between original exploration and actual mining of the material.

\section{Recommendations}

It is recommended that SANS/SAMREC set a standard for the reporting of Coal Resource and Coal Reserve tonnages based the type of deposit, and specify air-dry tonnages for the Mineable Resources. These tonnages would be derived from the airdry density of the resource matrix material, which is far more representative of the resource, in this case mineable coal, than a density derived for so-called in-situ values, including entrapped adventitious moisture. Water does not generate revenue!

\section{References}

GRAY, V.R. 1983. A formula for the mineral matter to ash ratio for low rank coals. Fuel, vol. 62. pp. 94-97.

Huang, H., Wang, K., Bodily, D.M., and Hucka, V.J. 1995. Density measurements of Argonne Premium coal samples. Energy \& Fuels, vol. 9. pp. 20-24.
KInG, J.G. and WiLKIns, E.T. 1944. The internal structure of coal. Proceedings of the Conference on the Ultra-fine Structure of Coals and Cokes, London, 1943. British Coal Utilization Research Association, London. pp. 46-56.

McEnaney, B. and Mays, T.J. 1989. Porosity in carbons and graphites. Introduction to Carbon Science. Marsh, H. (ed.), Butterworths, London. pp. 153-196.

Meyers, A., Clarkson, C., Wex, T., and Leach, B. 2004. Estimation of in-situ density of coal and relative density analyses. Final Report for ACARP Project C10042. Australian Coal Association Research Programme, Brisbane.

MorLey, C. 2003. Beyond reconciliation - A proactive approach to using mining data. Proceedings of the Fifth Large Open Pit Conference. Australasian Institute of Mining and Metallurgy, Melbourne. pp. 185-191.

NopPE, M. 2004. Reconciliation: Importance of good sampling and data QAQC. Proceedings of the Mining and Resource Geology Symposium, XYZ, EGRU Contribution no 62.

Preston, K. 2005. Estimating the in situ relative density of coal - Old favourites and new developments. Proceedings of the Bowen Basin Symposium 2005, The Future for Coal - Fuel for Thought, Yeppoon, Queensland. Beeston, J.W. (ed.). Geological Society of Australia Coal Geology Group and the Bowen Basin Geologists Group. pp. 13-22.

Preston, K.B. and SAnders, R.H. 1993. Estimating the in-situ relative density of coal. Australian Coal Geology, vol. 9, May. pp. 22-26.

Preston, K. and SAnders, R. 2005. Calculating reserves - A matter of some gravity. A study by Quality Coal Consulting Pty Ltd for Pacific Coal Pty Ltd.

ReEs, O.W. 1966. Chemistry, uses and limitations of coal analyses. Report of Investigations 220. Illinois State Geological Survey. 55 pp.

Roвеск , E. and Huo, D. 2015. Pure coal and mineral matter properties: A practical foundation for in situ density estimation. Peabody Energy, St. Lois, MO.

Roux. L. 2012. Optimal yield and cut density prediction of semi soft coking coal and powerstation coal in the Waterberg Coalfield, Limpopo Province. MSc dissertation, University of the Witwatersrand, Johannesburg.

Roux. L. 2017. The application of ash adjusted density in the evaluation of coal deposits. PhD thesis, University of the Witwatersrand, Johannesburg.

Roux, L. 2021. Density - A contentious issue in the evaluation and determination of Resources and Reserves in coal deposits. Journal of the Southern African Institute of Mining and Metallurgy, vol. 121, no. 5. pp. 227-250.

Unsworth, J.F., FowLer, C.S., and Jones, L.F. 1989. Moisture in coal: 2. Maceral effects on pore structure. Fuel, vol. 69. pp 18-26.

WARD, C.R. (ed.). 1984. Coal Geology and Coal Technology. Blackwell Scientific, Melbourne. 345 pp.

WARD, C.R. 2002. Analysis and significance of mineral matter in coal seams. International Journal of Coal Geology, vol. 46. pp. 67-82.

Wевв, P.A. 2001. Volume and density determinations for particle technologists. Micromeritics Instrument Corp., Norcross, GA. 